ENTREPRENEURSHIP AND SUSTAINABILITY ISSUES

ISSN 2345-0282 (online) http://jssidoi.org/jesi/

2019 Volume 7 Number 2 (December)

http://doi.org/10.9770/jesi.2019.7.2(22)

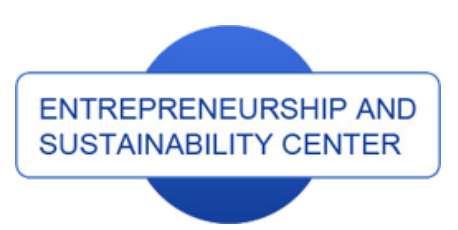

Publisher

http://jssidoi.org/esc/home

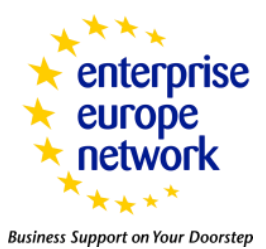

CASPA

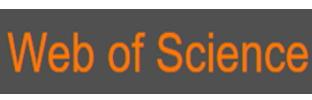

1) Clarivate

Analytics

\title{
INFLUENCE OF CORPORATE CULTURE ON THE SYSTEM OF MANAGEMENT IN MODERN CONDITIONS*
}

\author{
Khanif Sharifzyanovich Mullakhmetov', Ruslan Duferovich Sadriev², Elvir Munirovich Akhmetshin ${ }^{3^{*}}$ \\ ${ }^{1,2}$ Kazan Federal University, Naberezhnye Chelny Institute of KFU, Mira St., 68/19 (1/18), 423812, Naberezhnye Chelny, \\ Russia \\ ${ }^{3}$ Kazan Federal University, Elabuga Institute of KFU, Kazanskaya Street, 89, 423604, Elabuga, Russia \\ E-mail: $3^{*}$ elvir@mail.ru
}

Received 15 May 2019; accepted 12 October 2019; published 15 December 2019

\begin{abstract}
The main goal of the research of to reveal and classify sectoral and regional peculiarities, affecting the effectiveness of corporate culture use in the system of company management; to determine the character of this influence; to make conclusions on the possibilities of improvement of efficiency of the management at the businesses of the Republic of Tatarstan on the whole and in the petrochemical sector particularly. The authors developed their own conceptual system on the basis of which the research was conducted, namely: the authors' own understanding of a corporate culture was provided; its structure and functions are determined; factors of influence on corporate culture formation are revealed and classified. Increase of corporate culture role in the system of management, development of all its elements and functional extension compose significant reserve for the improvement of the efficiency of company management.
\end{abstract}

Keywords: management system; corporate culture; petrochemical sector; sectoral factors; regional factors; management effectiveness

Reference to this paper should be made as follows: Mullakhmetov, K.S., Sadriev, R.D., Akhmetshin, E.M. 2019. Influence of corporate culture on the system of management in modern conditions. Entrepreneurship and Sustainability Issues, 7(2), 1098-1113. http://doi.org/10.9770/jesi.2019.7.2(22)

JEL Classifications: A13, L70, M14

\footnotetext{
* The research described in this work was conducted in the framework of "Corporate Culture as a Tool of Management and Control in the Management System in the Competitive Environment (the case of the petrochemical sector of the Republic of Tatarstan)" Project, which is supported at the expense of funds received under Donation Agreement with BP Exploration Operating Company Limited No. c19-16 dated March 01, 2016 and designated for the implementation of the Research and Development Support Program
} 


\section{ENTREPRENEURSHIP AND SUSTAINABILITY ISSUES}

ISSN 2345-0282 (online) http://jssidoi.org/jesi/

2019 Volume 7 Number 2 (December)

http://doi.org/10.9770/jesi.2019.7.2(22)

\section{Introduction}

Now, under conditions of "new economics", based on constant generation of product, technological and organizational innovations, strategic competitive advantage is based at the level of business-processes, efficient functioning of which depends on the quality of management (Gafurov et al., 2012).

In virtue of drastic changes of factors of functional environment of modern organizations, the search of new concepts, systems and technologies of management for efficient management is required. The resulting vector of changes suggests transition to "soft management" in various forms (Adizes, 2017), (Hemel, 2009). In this case in the conducted researches a significant role is given to formation of positive corporate culture, agreed with the strategy of organization (Castells, 1996), (Castells, 1997), (Castells, 1998), (Thompson and Strickland, 2013), (McGoff, 2012), (Liker, and Hoseus, 2008), (Bernardi, 2019), (Girdzijauskaite et al., 2019).

The corporate culture, which has among other things guideline value, regulating activities and behavior of people by means of generally accepted informal rules, encourages flexibility and adaptivity of organizations. The authors of the book "Scenario planning: relationship between the future and strategy" singles out the following as the main question in their practical activity as the consultants: "How is it possible to compete successfully under everchanging conditions?" (Lindgren and Bandkhold, 2009). They think that the answer is the content of such concepts as strategic flexibility, strategic response capability, dynamic capabilities, dynamic core competences, strategic manoeuvring, competing on the edge, robust adaptiveness and "fanky" business. In particular the following contributions for the last 5 years of the 20th century were devoted to the concepts of "strategic flexibility": "Strategic maneuvering" (D'Aveni, Gunther, 2007), "Strategic reactivity" (Bettis, Hitt, 1995), "Dynamic core capability" (Lei, Hitt et al., 1996), "Dynamic potential" (Teece, Pisano et al., 1997), "Constant innovation" (Chakravarthy, 1997), "Strategic flexibility" (Hitt, Keats et al., 1998); Hamel (Hamel, 2000), "OODA cycle" (Haeckel, Nolan, 1993); (Blaxill, Hout, 1998), "Innovation of strategy" (Hamel, 1998), "Competition on the edge" (Brown, Eisenhardt, 1998), "Healthy" adaptability" (Beinhocken, 1999), "Business in "funky style" (Nordstrom, Ridderstrale, 1999). In fact, all the contributions offer adaptivity by means of surmounting of defense mechanisms, given by nature or acquired in the process of study and practice, using inner potential and, first of all management potential of organizations.

Enhancing the competitiveness level of economic entities is strategically dependent on creation and continuous maintenance, in the process of their functioning and development, more specifically, balance of flexibility and stability, providing efficient management. The problem is solved for each economic entity of its management under constant conditions: there are no ready universal receipts for all the times and they can't be developed; only general approaches, based on the theory of management and current experience are possible. Under given circumstances successful solutions of the problem are determined to a large extent by the level of management potential of the organization and human capital on the whole. Generalized groups of management transformation factors are given in (Mullakhmetov, 2018).

Traditional management, cultivated among other things in many organization of the Republic of Tatarstan, suggests determination of the system of parameters and maintenance of the activity of organization within these parameters. The procedure, provided by this means, decreases uncertainty level in the activity of organization, guarantees the effectiveness of management within short period of time. In this case modern organizations, being members of market relations, intensively affected by factors of environment, require constant changes.

An attempt to resolve contradictions between the order dictated by the hierarchy and the traditional management on the one hand and the necessity for continuous change dictated by the competitive market environment, on the other hand, by intensifying the goal-setting processes (continuously reviewing the strategy and the tactics for the implementation of strategic goals, breaking down the planning by periods, objects, doers, etc.) does not produce a 


\section{ENTREPRENEURSHIP AND SUSTAINABILITY ISSUES}

ISSN 2345-0282 (online) http://jssidoi.org/jesi/

2019 Volume 7 Number 2 (December)

http://doi.org/10.9770/jesi.2019.7.2(22)

desired effect of the enhanced management effectiveness. Such an approach is very costly and quickly becomes virtually inexpedient due to the characteristic features of a competitive environment (multifactorality, variability, uncertainty); it is not always applicable due to a number of restrictions. Fractal management, as possible solution of the problem, can be implemented under conditions of principal quality changes of human capital and management potential and specify increased requirements to the staff, which in its turn, requires cardinal reconstruction of training system of managers, mode of thinking and national culture on the whole (Mullakhmetov, 2018).

As a more delicate non-formal management tool, culture makes it possible to control and regulate human behavior at the level of social interaction, and, by so doing, enables to decrease, in the conditions of continuous changes of the environment wherein an organization functions and develops, the level of uncertainty when making managerial decisions; in case of a positive attitude and alignment with the strategy, the organizations will establish thereby the motives for the achievement of the chosen goals. Therefore, culture enhances the internal potential of an organization and its competitiveness.

The management within which a corporate culture serves as the balancing mechanism and wherein the cultural (symbolical) environment is regarded as an underlying factor determining the condition, development, methods and trends of the organization's activities may become a significant reserve for enhancing the effectiveness of management and control. M. Casson confirms that “... efficient culture has strong moral content. Moral can overcome problems, which can't be overcome by formal procedures, based on control over fulfillment of contract conditions. For this reason strong culture decreases transaction costs and increases productivity - success of economics depends on the quality of its culture" (Casson, 2006), (Cummings, 2010, p. 246).

The goal of this research is to reveal sectoral and regional factors, which have the greatest impact of the effectiveness of corporate culture use in the system of company management; to determine the character of their influence, to make conclusion about the possibilities of improvement of efficiency of the management at the enterprises of petrochemical sector the Republic of Tatarstan by means of increase of corporate culture role, as the factor of provision of management adaptivity.

\section{Methodology}

The methodological basis of the research consists in universal scientific research methods: analysis, synthesis, dialectic, abstraction, methods of system, logical, structural, comparative, statistical analysis, as well as graphical methods, methods of expert evaluations enabling to research the characteristics of the system of management and the subsystem of control in the light of continuous development and interrelation with the factors of the environment wherein an organization functions and develops.

The possibilities of the grounded theory are used as the main research strategy. Initially, a hypothesis is made regarding the existence of sectoral and regional peculiarities having a significant impact upon the effectiveness of using a corporate culture in the management system. Subsequently, the following shall be determined based on the analysis and comparison of the experts' opinions derived from the open sources (monographs, textbooks, teaching guides; dissertations; articles published in the Russian and overseas scientific editions), as well as based on the analysis of the publications regarding companies' activities, corporate web-sites, internal corporate documentation received from the open sources:

- the contemporary understanding of a corporate culture, its role and functions in a company management system;

- the main factors that influence the formation of a corporate culture;

- the practice of applying a corporate culture by the Russian and overseas companies in different spheres of activities; 


\section{ENTREPRENEURSHIP AND SUSTAINABILITY ISSUES}

ISSN 2345-0282 (online) http://jssidoi.org/jesi/

2019 Volume 7 Number 2 (December)

http://doi.org/10.9770/jesi.2019.7.2(22)

- sectoral and regional peculiarities of the petrochemical enterprises which influence the companies' management system.

The data accumulated in the course of the research are generalized and grouped in analytical tables by a certain attribute relevant for a certain stage of research. Thereafter, based on the analysis of the data provided, conclusions are made concerning the existence or absence of the sectoral and regional peculiarities influencing the effectiveness of using a corporate culture in the management system, as well as concerning the nature of such influence.

The methodology of research includes the following stages:

1. Analysis of theoretical aspects of forming a corporate culture of an organization;

1.1. What is understood under a corporate culture; the structure of a corporate culture.

1.2. Role and functions of a corporate culture in an organization.

1.3. Main factors influencing the formation of a corporate culture.

2. Generalization and analysis of the practical application of a corporate culture.

2.1. Structure of a corporate culture in an organization.

2.2. Main algorithms of operation of a corporate culture as a management and control tool.

2.3. Significance of a corporate culture in managing a company.

3. Analysis of peculiarities of the petrochemical sector.

3.1. Peculiar features of the petrochemical sector of the Russian Federation.

3.2. Peculiar features of the petrochemical sector of the Republic of Tatarstan.

3.3. Determining the factors that influence the management system of the petrochemical enterprises.

4. A comparative analysis of the practical application of the corporate culture at the enterprises of the Republic of Tatarstan with its Russia-wide and worldwide practical application.

4.1. Detection of the influence exerted by sectoral peculiarities on the effectiveness of using a corporate culture in the management system.

4.2. Detection of the influence exerted by regional peculiarities on the effectiveness of using a corporate culture in the management system.

\section{Results}

At the first stage, a conceptual system was developed based on which the work was conducted at the remaining stages of the research. In the context of management a corporate culture is a system of social standards and norms that are recognized and adopted by a majority of the organization's employees and that ensures a desired behavior and acts of the personnel based on the principles of self-management and self-control, developing horizontal links in the management system and facilitating the formation of informal institutes in the internal space of an organization. A corporate culture is viewed as a result of the response by the management to the changes of the market environment.

In our work we proceed from the following functions fulfilled by a corporate culture in the management system:

1. Decreasing complexity and uncertainty due to creating an internal institutional environment and enabling its continuity, and, hence, enhancing the quality and effectiveness of managerial decisions and of the entire management process.

2. Integrating function:

- joining the components of structures and processes on the basis of the generally accepted values;

- ensuring a relation between the mission and strategy with the day-to-day activities;

- team-building.

3. Enhancing the effectiveness of the personnel performance due to:

- motivation by uniting for general goals and commitment to lofty principles; 


\section{ENTREPRENEURSHIP AND SUSTAINABILITY ISSUES}

ISSN 2345-0282 (online) http://jssidoi.org/jesi/

2019 Volume 7 Number 2 (December)

http://doi.org/10.9770/jesi.2019.7.2(22)

- creating effective communications;

- improving the team climate.

4. A factor to ensure the balance between the consistency and flexibility of management.

5. Creating a distinguishing favorable image for the external environment.

The corporate culture structure we offer is as follows:

1. Value basis of a company (company mission, corporate goals and the goals of the company's top management and owners, main values of the company's top management and owners);

2. Value basis of the corporate culture;

3. Functions of a corporate culture as a management and control tool;

4. Manifestation of a corporate culture;

5. A mechanism for implementation of a corporate culture as a management and control tool (the indicators assessed, the persons responsible, the verification method).

Taking into account the peculiarities of the contemporary management, we shall subsequently proceed from an assumption that the following groups of factors influence the formation of a corporate culture:

1. External factors:

- location, environment, situation in the society and economy, peculiarities of the market, sectoral specifics;

- contacts with various groups concerning different events and actions taken by organizations (for example, the work with the Western companies is important for the Russian enterprises);

- essential changes in the properties of a human capital (educational level, civic maturity, changes in motivation);

- dynamic growth of the uncertainty level of the business environment;

- cultural environment (national, regional, business cultures).

2. Internal factors:

- the organization's history of establishment and representation of the top officials;

- characteristic features of an organization (kinds of activity, size, basic functions and technologies, goals and objectives, ownership forms);

- characteristic features of the management system (leadership style, correlation of formal and non-formal institutes, work with the personnel, personal properties of a manager/leadership properties);

- personal system of values and rules of the workforce;

- experience of interaction with the external environment.

In the course of analyzing the practical application of the corporate culture by the Russian and overseas enterprise we researched the activities of 10 companies, of which 8 were from the petrochemical and 2 -companies from the automotive sector. 2 major overseas companies (Shell, British Petroleum), 2 major Russian companies (Rosneft, Gazprom) and 4 leading Tatarstan companies of this sector (Tatneft, Nizhnekamskneftekhim, Kazanorgsintez, Ammoniy) from petrochemical sector were examined. In order to gain a more complete picture of the contemporary tendencies in the development of the corporate culture and for the purpose of comparative analysis and assessment of the leading companies in the automobile sector were also researched, Toyota and KAMAZ. The information for the analysis of the companies was derived from the open sources.

The research resulted in the following findings:

1. The level of the corporate culture artifacts in the absolute majority of the researched companies is sufficiently well developed (the companies carry out full-fledged work on forming the external level of the corporate culture).

2. Most of researched companies have gaps in many trends at the level of the corporate culture values. 


\section{ENTREPRENEURSHIP AND SUSTAINABILITY ISSUES}

ISSN 2345-0282 (online) http://jssidoi.org/jesi/

2019 Volume 7 Number 2 (December)

http://doi.org/10.9770/jesi.2019.7.2(22)

3. The corporate values system in all of the companies is highly developed; however, we were not always able to definitely track, based on the open sources alone, the mechanisms of interaction of the corporate values system (missions, strategic objectives, etc.) with the values of the companies' corporate culture.

4. As a management and control tool the corporate culture may manifest itself as follows:

- it may influence the personnel management system, namely, determine the systems for personnel hiring, dismissal, reward, punishment, development, career advancement. According to the open sources, in the majority of the researched companies the corporate culture only exerts a partial influence on the personnel management system. Thus, it was discovered that all companies have put in place their own personnel development systems, and, with very few exceptions, the personnel hiring systems. The remaining elements of the personnel management system are either underdeveloped or altogether absent;

- to facilitate socialization of the employees, form the labor conditions (these elements are well developed in all of the researched companies);

- to facilitate development of horizontal, vertical and direct backward links in the management system (in the absolute majority of the researched companies the corporate culture has little influence on the establishment of the aforementioned kinds of links);

- to influence the characteristic features of the management system (priority of the social and humanitarian component, active participation of employees in the adoption of managerial decision, reduction of the management levels, quick response to the requests of the company employees, removal of barriers between the management and the subordinates). According to the accumulated data, in the absolute majority of the researched companies the influence of the characteristic features of the corporate culture upon the characteristic features of the management system is limited.

5. An inference can be made that among the researched companies the corporate culture plays the crucial role in Toyota only. Democratic principles of governance and "soft" methods of control are developed here. The analyzed managerial procedures are standardized and definitively formulated in the company. Almost all of the indications evidencing the significance of the corporate culture in the company's management were detected.

The research uncovered the sector-wide, national and regional factors determining the specific features of the petrochemical sector. Those factors were subdivided into the following groups:

- institution-specific;

- infrastructure-specific;

- economic;

- market-specific;

- those related with the staffing and provision of resources;

- those related with investments and accessibility of funds;

- those related with the technical and technological bases;

- those related with the corporate management and property rights protection;

- those related with management and corporate culture.

\section{Discussion}

At the moment there is no uniform understanding of corporate culture and its structure; the role of corporate culture in modern management; the means the functions of corporate culture are implemented by; factors, which determine characteristics and role of corporate culture in the organization, the possibility of their quantitative assessment; tools of corporate culture, which can affect the internal environment and eliminate contradictions of management system.

1. The following groups of opinions on those matters were singled out:

a) most often, a corporate culture is understood as follows: 


\section{ENTREPRENEURSHIP AND SUSTAINABILITY ISSUES}

ISSN 2345-0282 (online) http://jssidoi.org/jesi/

2019 Volume 7 Number 2 (December)

http://doi.org/10.9770/jesi.2019.7.2(22)

Table 1. Groups of Concepts of "Corporate Culture"

\begin{tabular}{|c|c|}
\hline $\begin{array}{l}\text { What the author is primarily focused on in the } \\
\text { concept of "corporate culture" }\end{array}$ & Sources \\
\hline $\begin{array}{l}\text { 1. Key values/values system / value-based and regulatory } \\
\text { space }\end{array}$ & $\begin{array}{l}\text { (Biletskaya, E., 2008), (Karlof, B., \& Lovingsson, F., 2006), (Vetoshkina, T., } \\
\text { 2009), (Daft, R., 2006), (George, J, Jones, G., 2003), (Liker, J., 2017), } \\
\text { (Mogutnova, N., 2005), (Robins, S. P., Coulter, M., 2004), (Thompson, Jr., A., } \\
\text { A., Strickland III, A., J., 2013) }\end{array}$ \\
\hline $\begin{array}{l}\text { 2. Collective basic vision/totality of basic assumptions } \\
\text { (myths)/totality of basic beliefs/a system of publicly and } \\
\text { collectively acceptable notions/totality of the most } \\
\text { important mutual understandings }\end{array}$ & $\begin{array}{l}\text { (Gaponova, O., 2011), (Kozlov, V., 2009), (Kondratyev, E., 2011), (Cooper, } \\
\text { C., 2014), (Mullins, L., 2003), (Porshnev, A., 2012), (Kibanov, A., 2003), } \\
\text { (Shermerorn, J., Hunt, J., Osborne, R., 2004) }\end{array}$ \\
\hline $\begin{array}{l}\text { 3. The observed recurring behavioral models/totality of } \\
\text { standards and stereotypes of employee behavior }\end{array}$ & (Gaponova, O., 2011), (Krylov, B., 2010) \\
\hline 4. Norms/principles/ rules/game rules & (Selivanova, M., 2016) \\
\hline 5. Sensation or climate/organization's environment & (Zakablutskaya, E., 2014), (Pierce, II. J., Robinson, R., 2013) \\
\hline 6. Problem solving methods acquired through experience & (Gaponova, O., 2011), (Sarkisov, S., 2005) \\
\hline $\begin{array}{l}\text { 7. A method for describing key characteristics of } \\
\text { organizations and business. The organization represents } \\
\text { analogy to culture. }\end{array}$ & (Cummings, S. (2010), (Ackoff, R., 1970). \\
\hline $\begin{array}{l}\text { 8. The essence of an organization/key comparison in the } \\
\text { organization's concept/internal component of an } \\
\text { organization; }(19,20) \text {. }\end{array}$ & $\begin{array}{l}\text { (Greenberg, D., \& Beyron, R., 2004), (Liker, J, 2017), (Krol, L., Purtova, E., } \\
\text { 2004), (Smircich, L., 1983), (Smircich, L., 1985) }\end{array}$ \\
\hline $\begin{array}{l}\text { 9. Factor influencing the effectiveness of the economic } \\
\text { activity/factor uniting the organization's employees }\end{array}$ & $\begin{array}{l}\text { (Karlof, B., \& Lovingsson, F., 2006), (Vlasova, E., 2010), (Gaydarzhi, E., } \\
\text { 2007), (Korotkov, E., 2004), (Mullins, L., 2003), (Sarkisov, S., 2005) }\end{array}$ \\
\hline $\begin{array}{l}\text { 10. Corporate culture is an innovative cultural form, } \\
\text { distinct from organizational culture }\end{array}$ & (Kapitonov, E. A., Zinchenko, G. P., Kapitonov, A. E., 2005) \\
\hline $\begin{array}{l}\text { 11. Generated in the result of cooperation of internal } \\
\text { factors of belief system, ideas, related to company } \\
\text { management, the strategy of its development, means and } \\
\text { methods of achieving goals and management decisions } \\
\text { making, with business ethics of the organization, which } \\
\text { shows its main values, shared by the majority of staff } \\
\text { members, aimed at the improvement of inner potential of } \\
\text { the organization. }\end{array}$ & (Mullakhmetov et al., 2018) \\
\hline
\end{tabular}

b) the following functions performed by the corporate culture are singled out most often:

Table 2. Basic Functions Performed by the Organization's Corporate Culture

\begin{tabular}{|c|c|}
\hline Functions Performed by a Corporate Culture & Sources \\
\hline $\begin{array}{l}\text { 1. Relation of a mission and strategy with the day-to-day } \\
\text { activities }\end{array}$ & (Gaponova O., 2011), (Selivanova M., 2016) \\
\hline $\begin{array}{l}\text { 2. Increasing consistency of the company's performance } \\
\text { due to forming a definite internal institutional environment } \\
\text { and ensuring its continuity }\end{array}$ & $\begin{array}{l}\text { (Gaponova, O., 2011), (Daft, R., 2006), (Mogutnova, N., 2005), (Panferova, } \\
\text { N., 2011) }\end{array}$ \\
\hline $\begin{array}{l}\text { 3. Management and control tool: consciously generating } \\
\text { positive corporate culture, you can influence behavior and } \\
\text { activity of the staff, which determine performance and } \\
\text { effectiveness of the organization. }\end{array}$ & (Mullakhmetov et al., 2018) \\
\hline 4. Enhancement of the personnel performance efficiency & $\begin{array}{l}\text { (Gaponova, O., 2011), (Daft, R., 2006), (Yemelyanov, Yu., Khachaturian, } \\
\text { A., 2009), (Korotkov, E., 2004), (Kukura, S., 2004), (Mogutnova, N., } \\
\text { 2005), (Panferova, N., 2011), (Selivanova, M., 2016) }\end{array}$ \\
\hline
\end{tabular}




\section{ENTREPRENEURSHIP AND SUSTAINABILITY ISSUES}

ISSN 2345-0282 (online) http://jssidoi.org/jesi/ 2019 Volume 7 Number 2 (December) http://doi.org/10.9770/jesi.2019.7.2(22)

\begin{tabular}{|l|l|}
\hline $\begin{array}{l}\text { 5. Enhancement of manageability of an organization at the } \\
\text { expense of creating effective internal communications }\end{array}$ & (Daft, R., 2006), (Mogutnova, N., 2005), (Selivanova, M., 2016) \\
\hline 6. Creating a distinctive image for the external audiences & (Gaponova, O., 2011), (Mogutnova, N., 2005), (Panferova, N., 2011) \\
\hline 7. Decreasing the complexity and uncertainty & (Kukura, S., 2004), (Mullins, L., 2003), (Krol, L., Purtova, E., 2004) \\
\hline $\begin{array}{l}\text { 8. Employee motivation due to commitment to lofty } \\
\text { principles and unification for achievement of common goals }\end{array}$ & (Daft, R., 2009) \\
\hline 9. Joining structural subdivisions and their integration & (Schein, E., 2013) \\
\hline $\begin{array}{l}\text { 10. Improvement of climate in the collective due to } \\
\text { employee satisfaction }\end{array}$ & (Mazur, I., 2003), (Pierce, II. J., Robinson, R., 2013) \\
\hline 11. Enhancement of competitiveness & (Thompson, Jr. A. A., Strickland III, A. J., 2013), (Kibanov. A., 2003) \\
\hline 12. Team-building & (Cooper, C., 2014) \\
\hline
\end{tabular}

c) the following factors influencing the formation of the corporate culture are singled out most often:

Table 3. Basic Factors Influencing the Corporate Culture Formation

\begin{tabular}{|c|c|}
\hline Factors Influencing the Corporate Culture Formation & Sources \\
\hline \multicolumn{2}{|c|}{ External factors } \\
\hline - national/ regional culture & $\begin{array}{l}\text { (Neretina, E., 2006), (Panferova, N., 2011), (Pervakova, E. 2015), } \\
\text { (Torgunakova, E., 2010) }\end{array}$ \\
\hline - business specifics, business culture & (Neretina, E., 2006), (Panferova, N., 2011), (Pervakova, E. 2015) \\
\hline - industry specifics & (Panferova, N., 2011) \\
\hline - market specifics & (Pervakova, E. 2015) \\
\hline - situation in economy, society & (Pervakova, E. 2015) \\
\hline $\begin{array}{l}\text { - samples of conducting entrepreneurial activities by the } \\
\text { management companies }\end{array}$ & (Pervakova, E. 2015) \\
\hline - history, location, environment & (Mullins, L., 2003) \\
\hline $\begin{array}{l}\text { - contacts with different groups concerning different events } \\
\text { and acts of an organization }\end{array}$ & (Greenberg, D., \& Beyron, R., 2004) \\
\hline $\begin{array}{l}\text { - dynamic growth of the level of uncertainty of the } \\
\text { environment }\end{array}$ & (Schein, E., 2013) \\
\hline $\begin{array}{l}\text { - change of environmental factors that significantly affect the } \\
\text { functioning and development of modern organizations }\end{array}$ & (Adizes, I. 2017), (Kibanov, A., 2003), (Akmaeva, 2017) \\
\hline \multicolumn{2}{|c|}{ Internal factors: } \\
\hline - representation of top managers & (Panferova, N., 2011) \\
\hline - ownership form & (Torgunakova, E., 2010) \\
\hline - production technologies & (Torgunakova, E., 2010) \\
\hline - employee personal system of norms and values & (Neretina, E., 2006) \\
\hline $\begin{array}{l}\text { - basic functions and technologies, goals and objectives, size, } \\
\text { employee management and recruitment system }\end{array}$ & (Mullins, L., 2003) \\
\hline $\begin{array}{l}\text { - company founders, experience of interaction with } \\
\text { environment }\end{array}$ & (Greenberg, D., \& Beyron, R., 2004) \\
\hline $\begin{array}{l}\text { - company founders; ethical values, rules and standards that } \\
\text { reflect them }\end{array}$ & (George, J, Jones G., 2003) \\
\hline $\begin{array}{l}\text { - a good leadership component (vision, personal example, } \\
\text { insistence and principles) }\end{array}$ & (Pierce, II. J., Robinson, R., 2013) \\
\hline - managerial ideology and managerial potential & (Kukura, S., 2004) \\
\hline $\begin{array}{l}\text { - fundamental changes in the characteristics of human capital } \\
\text { and socio-cultural factors }\end{array}$ & \\
\hline
\end{tabular}

\section{Conclusion}

The petrochemical enterprises' culture has a number of generalized characteristic features.

1. A high level of artifacts of the companies' corporate culture, with the enterprises normally carrying out full-fledged work for forming the external level of the corporate culture. 


\section{ENTREPRENEURSHIP AND SUSTAINABILITY ISSUES}

ISSN 2345-0282 (online) http://jssidoi.org/jesi/ 2019 Volume 7 Number 2 (December) http://doi.org/10.9770/jesi.2019.7.2(22)

2. At the level of the values of the companies' corporate culture gaps were detected in many trends: those values are either underdeveloped or are predominantly declarative and not based on the actual mechanism of implementation of the declared values.

3. The enterprises have a well-developed system of corporate values, but the mechanisms of interrelation of the corporate values system (missions, strategic objectives, etc.) with the corporate values culture weakly manifest themselves in the companies.

4. As a management and control tool the corporate culture may be manifested as follows:

a) to influence the personnel management system, namely, determine the systems for personnel hiring, dismissal, reward, punishment, development, horizontal and vertical career advancement (in the petrochemical sector the corporate culture only exerts a partial influence on the personnel management system);

b) to facilitate employee socialization, to create the labor conditions (those elements are well-developed in the petrochemical companies);

c) to facilitate horizontal, vertical, direct backward links in the management system (in the majority of companies the corporate culture has little influence on the establishment of links);

d) to influence the characteristic features of the management system (priority of the social and humanitarian component, active participation of employees in the adoption of managerial decision, reduction of the management levels, quick response to the requests of the company employees, removal of barriers between the management and the subordinates (in the absolute majority of the researched companies the influence of the characteristic features of the corporate culture upon the characteristic features of the management system is limited).

5. The significance of the corporate culture in the management is weakly manifested in the petrochemical businesses.

\section{Summary}

Based on the results of the research the specific regional and regional factors influencing the management system of the petrochemical enterprises were determined (Table 4 and Table 5).

Table 4. Sector-Wide Factors Influencing the Management System and Corporate Culture of the Petrochemical Enterprises

\begin{tabular}{|c|c|c|}
\hline $\begin{array}{l}\text { Factor determining the specific } \\
\text { features of the petrochemical } \\
\text { sector }\end{array}$ & Factor Description & $\begin{array}{l}\text { Where it is reflected in the organization's } \\
\text { activities }\end{array}$ \\
\hline \multirow[t]{4}{*}{$\begin{array}{l}\text { Institutional factors related with the } \\
\text { actions of authorities }\end{array}$} & $\begin{array}{l}\text { Strong influence of environmental protection } \\
\text { requirements }\end{array}$ & $\begin{array}{l}\text { Development of corporate programs related } \\
\text { with the environmental protection }\end{array}$ \\
\hline & $\begin{array}{l}\text { Active participation of the state in the creation of } \\
\text { petrochemical clusters }\end{array}$ & $\begin{array}{l}\text { Establishment and development of close } \\
\begin{array}{l}\text { connections } \\
\text { structures }\end{array}\end{array}$ \\
\hline & $\begin{array}{l}\text { Effective development of the national } \\
\text { petrochemical industry is largely dependent on the } \\
\text { character and degree of the state participation of } \\
\text { the state in this process }\end{array}$ & $\begin{array}{l}\text { Establishment and development of close } \\
\text { relations with the federal authorities }\end{array}$ \\
\hline & $\begin{array}{l}\text { The Russia's government follows the policy of } \\
\text { supporting the major integrated oil companies and } \\
\text { industry consolidation }\end{array}$ & Formation of the administrative resource \\
\hline Infrastructural & $\begin{array}{l}\text { Priority of the cluster development of the industry, } \\
\text { formation of } 6 \text { petrochemical clusters }\end{array}$ & $\begin{array}{l}\text { Establishment and development of close } \\
\text { inter-sector relations }\end{array}$ \\
\hline
\end{tabular}


ENTREPRENEURSHIP AND SUSTAINABILITY ISSUES

ISSN 2345-0282 (online) http://jssidoi.org/jesi/

2019 Volume 7 Number 2 (December)

http://doi.org/10.9770/jesi.2019.7.2(22)

\begin{tabular}{|c|c|c|}
\hline & $\begin{array}{l}\text { Availability of major vertically integrated } \\
\text { structures }\end{array}$ & $\begin{array}{l}\text { Establishment and development of close } \\
\text { relations with other enterprises involved in } \\
\text { technological production chains }\end{array}$ \\
\hline & $\begin{array}{l}\text { Insufficient integration of the petrochemical } \\
\text { complex production enterprises }\end{array}$ & $\begin{array}{l}\text { Establishment and development of close } \\
\text { inter-sector relations }\end{array}$ \\
\hline \multirow[t]{3}{*}{ Economic } & High growth rates & $\begin{array}{l}\text { Растет уровень зарплат в } \\
\text { появляются дополнительные } \\
\text { стимулирования персонала }\end{array}$ \\
\hline & $\begin{array}{l}\text { Shift of large-scale petrochemical production } \\
\text { enterprises }\end{array}$ & \multirow[t]{2}{*}{$\begin{array}{l}\text { Establishment and development of inter- } \\
\text { governmental relations }\end{array}$} \\
\hline & $\begin{array}{l}\text { Shift of the focus of traditional petrochemical } \\
\text { regions }\end{array}$ & \\
\hline \multirow[t]{2}{*}{$\begin{array}{l}\text { Factors related with the technical and } \\
\text { technological bases }\end{array}$} & $\begin{array}{l}\text { The chemical complex is one of the most science- } \\
\text { driven sectors }\end{array}$ & $\begin{array}{l}\text { Development of the Research and } \\
\text { Development Programs }\end{array}$ \\
\hline & $\begin{array}{l}\text { Complexity and close technical relationship of } \\
\text { different production stages and use of resources }\end{array}$ & $\begin{array}{l}\text { Establishment and development of close } \\
\text { relationships with other enterprises involved } \\
\text { in technological production chains }\end{array}$ \\
\hline \multirow{4}{*}{$\begin{array}{l}\text { Factors related with corporate } \\
\text { management and protection of } \\
\text { ownership rights }\end{array}$} & $\begin{array}{l}\text { Drop in the level of confidence between the } \\
\text { management and the company employees }\end{array}$ & $\begin{array}{l}\text { Development of internal communications, } \\
\text { formation of a corporate culture }\end{array}$ \\
\hline & $\begin{array}{l}\text { The gaspetrochemical complex was exposed to a } \\
\text { frequent change of control; there were illegal } \\
\text { takeovers of the assets }\end{array}$ & \multirow[t]{2}{*}{$\begin{array}{l}\text { Creation of the corporate control systems, } \\
\text { including those government-linked }\end{array}$} \\
\hline & $\begin{array}{l}\text { A part of oil companies got involved in shadow } \\
\text { business }\end{array}$ & \\
\hline & $\begin{array}{l}\text { When products were high-priced, the company } \\
\text { owners used to spend a considerable portion of } \\
\text { profits for paying dividends rather than upgrading } \\
\text { their enterprises }\end{array}$ & Development of financial control \\
\hline
\end{tabular}

Table 5. Regional Factors Influencing the Management System and the Corporate Culture of the Petrochemical Enterprises

\begin{tabular}{|c|c|c|}
\hline Regional Factor & Factor Description & $\begin{array}{c}\text { Where it is reflected in the organization's } \\
\text { activities }\end{array}$ \\
\hline \multirow[t]{3}{*}{ Infrastructural factors } & $\begin{array}{l}\text { Tatarstan is included in the Volga-region } \\
\text { gaspetrochemical cluster }\end{array}$ & $\begin{array}{l}\text { Establishment and development of close } \\
\text { inter-sectoral and intra-sectoral relationships }\end{array}$ \\
\hline & \multirow{2}{*}{$\begin{array}{l}\text { Availability of a well-developed transportation } \\
\text { infrastructure and manifold regional and foreign } \\
\text { economic relationships }\end{array}$} & $\begin{array}{l}\text { Establishment and development of inter- } \\
\text { regional relationships }\end{array}$ \\
\hline & & $\begin{array}{l}\text { Establishment and development of } \\
\text { international relationships }\end{array}$ \\
\hline Economic & $\begin{array}{l}\text { The gaspetrochemical complex is the basic sector } \\
\text { of the Republic of Tatarstan's industry. It has the } \\
\text { cardinal significance for the functioning of all the } \\
\text { sectors of the economies of the Republic of } \\
\text { Tatarstan and Russian Federation. }\end{array}$ & $\begin{array}{l}\text { Establishment of the corporate control } \\
\text { systems, including those with the } \\
\text { participation of the regional authorities. }\end{array}$ \\
\hline Market-related & $\begin{array}{l}\text { The Republic of Tatarstan tops Russia in terms of } \\
\text { the majority of foreign economic transactions }\end{array}$ & New personnel incentives have appeared \\
\hline \multirow[t]{2}{*}{$\begin{array}{l}\text { Factors related with the technical and } \\
\text { technological bases }\end{array}$} & $\begin{array}{l}\text { The Republic of Tatarstan hosts a number of the } \\
\text { gaspetrochemical companies that are the largest } \\
\text { not only in Russia, but in Europe as well }\end{array}$ & \multirow[t]{2}{*}{$\begin{array}{l}\text { Entering new markets, output of new } \\
\text { commodities }\end{array}$} \\
\hline & In the coming years, he gaspetrochemical complex & \\
\hline
\end{tabular}


The petrochemical enterprises are characterized by a number of sectoral and regional peculiarities having both a positive and a negative impact upon the effectiveness of using a corporate culture in the management system. The following may be regarded as positive:

Sector-related factors:

- a tradition to maintain plant museums; a growth of interest of the oil-sector companies' employees to the history of their sector; development of publishing and exhibition activities; traditions of maintaining professional skills, awarding titles of those best in the occupation, recognition of veterans of war and labor; a higher level of income and salaries as opposed to other sectors, new employee incentives;

- a high level of artifacts of the companies' corporate culture, with the enterprises normally conducting work aimed at reaching the highest level of the corporate culture;

- a system of corporate values is well-developed in the petrochemical companies;

- a corporate culture may sufficiently facilitate socialization of employees and create labor conditions at the petrochemical companies.

Regional factors:

- a profound sense of duty and responsibility in every company employee;

- avoidance of conflicts, and if any arise, the participants make mutual concessions and reach a consensus;

- good interpersonal relationships, comfortable psychological climate in the labor teams.

The factors that have a negative influence on the effectiveness of using a corporate culture in the management system of the petrochemical companies are as follows.

Sectoral factors:

- At the level of the values of the companies' corporate culture gaps exist in many trends: those values are either underdeveloped or predominantly declarative and not based on the actual mechanism of implementation of the declared values.

- The mechanisms of interrelation of the corporate values system (missions, strategic objectives, etc.) with the corporate values culture weakly manifest themselves in the companies.

- In the absolute majority of the petrochemical companies the corporate culture has little influence upon the development of horizontal, vertical and direct backward links in the management system;

- the petrochemical companies experience limited influence from the characteristic features on the characteristic features of the corporate culture.

- great significance of the administrative resource;

- great significance of establishment and development of close relationships with the federal authorities, of intra-sectoral and inter-sectoral relationships, relations with other enterprises included in the technological production chains.

Regional factors: authorities;

- great significance of establishment and development of close relationships with the regional and local

- predominance of a bureaucratic (hierarchical) culture;

- authoritarian leadership style;

- hierarchical relations, authority of a job title, discipline and order are the basic values at an enterprise;

- avoidance of risks, prioritization of companies' goals; 


\section{ENTREPRENEURSHIP AND SUSTAINABILITY ISSUES}

ISSN 2345-0282 (online) http://jssidoi.org/jesi/

2019 Volume 7 Number 2 (December)

http://doi.org/10.9770/jesi.2019.7.2(22) activities.

- formalism, leading role of instructions and procedures, authoritarianism, low initiative and low creative

Therefore, only certain corporate culture components are sufficiently developed at the petrochemical enterprises of the Republic of Tatarstan, i.e., those that are mainly connected with the external level of the corporate culture, whilst within the companies the number of functions that the corporate culture performs is limited. A number of sectoral and regional factors, both positive and negative, have an impact upon the effectiveness of using a corporate culture in the petrochemical companies' management system, with the factors that negatively influence the effectiveness of using a corporate culture in the management system being predominant.

Among those the most essential are the significance of administrative resources, authoritarian leadership style and formal management methods.

All of that to a large extent results in the corporate culture having low significance for company management at the petrochemical enterprises of the Republic of Tatarstan, which only confirms that there is an essential reserve for boosting the company management effectiveness at the expense of enhancing the corporate culture significance, broadening its functions and developing all of its components.

The existing level of the corporate culture development at the Republic of Tatarstan's enterprises as a whole, and at the petrochemical enterprises in particular means that underdeveloped social and cultural toolkit in the management system is today one of the main factors preventing the introduction of new effective management systems and technologies.

The business environment of the Russian companies has, due to a variety of reasons, underdeveloped market institutes, whilst the already existing ones differ from their analogues in the developed market, which causes additional difficulties for putting in place new technologies. In addition, the management effectiveness decreases due to the applicable technologies of development, adoption and implementation of managerial decision in the framework of the strict hierarchy under the conditions of a minimum formalized involvement of personnel in that process, as well as to the stiff control procedures aimed at assessing the actions of the personnel, thus nurturing their sense of duty rather than initiative and creativity.

Enterprise management in the petrochemical sector is mainly aimed at stability; characteristics determined in the process of research can't guaranty the required level of flexibility (adaptivity) in modern business environment.

\section{Aknowledgements}

The research described in this work was conducted in the framework of "Corporate Culture as a Tool of Management and Control in the Management System in the Competitive Environment (the case of the petrochemical sector of the Republic of Tatarstan)" Project, which is supported at the expense of funds received under Donation Agreement with BP Exploration Operating Company Limited No. c19-16 dated March 01, 2016 and designated for the implementation of the Research and Development Support Program. 


\section{ENTREPRENEURSHIP AND SUSTAINABILITY ISSUES}

ISSN 2345-0282 (online) http://jssidoi.org/jesi/

2019 Volume 7 Number 2 (December)

http://doi.org/10.9770/jesi.2019.7.2(22)

\section{References}

Ackoff, R. L. (1970). A Concept of Corporate Planning. New York, NY: Wiley.

Adizes, I. (2017). Theory and practice of management transformation before new challenges - Russia has to catch up. Harvard Business Review - Russia, January-February: 6-10.

Beinhocken, E. D. (1999). Robust adaptive strategies. Sloan Management Review, 40(3): 95-106.

Bernardi, A. (2019). The capability approach and organizational climate as tools to study occupational health and safety. Insights into Regional Development, 1(2), 155-169. https://doi.org/10.9770/ird.2019.1.2(6)

Bettis, R. A., Hitt, M. A. (1995). The new competitive landscape. Strategic Management Journal, 16: 7-16.

Biletskaya, E. (2008). "That it is good that it is bad": Development and deployment of corporate values (project). Reference book on personnel management, 10: 84-88.

Blaxill, M. F., Hout, T. M. (1998). Make decisions like a fighter pilot. In: Perspectives on Strategy. C. W. Stern, G.J. Stalk. New York: John Wiley.

Brown, S. L., Eisenhardt, K. M. (1998). Competing on the Edge. Boston, MA: Harvard Business School Press.

Casson, M. (2006). Chapter 12 culture and economic performance. Handbook of the Economics of Art and Culture, 1: 359-397. https://doi.org/10.1016/S1574-0676(06)01012-X

Castells, M. (1996). The rise of the network society. The Information Age: Economy, Society and Culture. Malden, MA: Blackwell.

Castells, M. (1997). The Power of Identity. The Information Age: Economy, Society and Culture. Malden, MA: Blackwell.

Castells, M. (1998). End of Millennium. The Information Age: Economy, Society and Culture. Malden, MA: Blackwell.

Chakravarthy, B. (1997). A new strategy framework for coping with turbulence. Sloan Management Review, Winter: 69-82.

Cooper, C. L. (2014). School of leadership. Technology of effective management. Saint Petersburg: Ves' Publishing group.

Cummings, S. (2010). Reconstruction strategy. Kharkov: Publishing house Humanitarian Centre.

Daft, R. L. (2006). Corporate culture: the theory and practice from Richard Daft. The marketing specialist, 12: 56-62.

Daft, R. L. (2009). Management (8th ed.). St. Petersburg: Piter.

D’Aveni, R. A., Gunther, R. (2007). Hypercompetition. Managing the Dynamics of Strategic Maneuvering. In: Boersch, C., Elschen, R. (eds) Das Summa Summarum des Management. Wiesbaden: Gabler.

Gafurov, I. R., Safiullin, M. R., Safiullin, A. R. (2012). The Analysis of Competitiveness Structural Gaps in the Production of Petrochemical Cluster in the Republic of Tatarstan. Kazan: Kazan University

Gaponova, O. S. (2011). Assessment of motivational aspect of forming of corporate culture of the organization. Economic analysis: theory and practice, $32,43-50$.

Gaydarzhi, E. S. (2007). Influence of corporate culture on efficiency of activity of collective subjects of work (the thesis for a degree of the candidate of psychological sciences). Moscow: Lomonosov Moscow State University.

George, J. M., \& Jones, G. R. (2003). Organizational behavior. Bases of management (the education guidance for higher education institutions). Moscow: Unity-Dana. 


\section{ENTREPRENEURSHIP AND SUSTAINABILITY ISSUES}

ISSN 2345-0282 (online) http://jssidoi.org/jesi/

2019 Volume 7 Number 2 (December)

http://doi.org/10.9770/jesi.2019.7.2(22)

Girdzijauskaite, E., Radzeviciene, A., Jakubavicius, A. (2019). Impact of international branch campus KPIs on the university competitiveness: FARE method. Insights into Regional Development, 1(2), 171-180. https://doi.org/10.9770/ird.2019.1.2(7)

Greenberg, D., \& Beyron, R. (2004). Organizational Behavior: From the Theory to Practice. Moscow: LLC "Vershina".

Haeckel, S., Nolan, R. L. (1993). Managing by wire. Harvard Business Review, September-October.

Hamel, G. (1998). Strategy innovation and the quest for value. Sloan Management Review, Winter: 7-14.

Hamel, G. (2000). Leading the Revolution. Boston, MA: Harvard Business School Press.

Hemel, G. (2009). Management 2.0: The new version for the new century. Harvard Business Review - Russia, October 2009: 91-100.

Hitt, M. A., Keats, B. W., \& DeMarie, S. M. (1998). Navigating in the new competitive landscape: Building strategic flexibility and competitive advantage in the 21st century. Academy of Management Executive, 12(4): 22-42.

Kapitonov, E. A., Zinchenko, G. P., Kapitonov, A. E. (2005). Corporate culture: theory and practice. Moscow: Alpha Press. (In Russian).

Karlof, B., \& Lovingsson, F. H. (2006). The A-Z management: concepts and models (pp. 159-161). Saint Petersburg: Stockholm School of Economics in Saint Petersburg.

Kibanov, A. Ya. (2003). Personnel management of the organization (2nd ed.). Moscow: INFRA-M.

Kondratyev, E. (2011). Organization culture: concept, mechanism and methods of management. Theoretical and Practical Aspects of Management, 11, 56-64.

Korotkov, E. M. (2004). Concept of the Russian management. Moscow: LLC Publishing and Consulting Enterprise "DEKA".

Kozlov, V. V. (2009). Corporate culture: educational and practical benefit. Moscow: Alfa-Press publishing house.

Krol, L. M., \& Purtova, E. A. (2004). Managerial culture of the organizations. Moscow: Klass independent firm.

Krylov, B. (2010). Corporate culture: to understand and measure (a research of corporate culture on the example of the American corporation "Kompak". Examples of questions). Reference book on personnel management, 8, 25-32.

Kukura, S. P. (2004). Theory of corporate management. Moscow: Ekonomika Publishing House.

Lei, D., Hitt, M. A., Bettls, R. (1996). Dynamic core competences through meta- learning and strategic content. Journal of Management, 22(4), p. 549-569.

Liker, J. K., \& Hoseus, M. (2008). Toyota Culture: The Heart and Soul of the Toyota Way. New York, NY: McGraw-Hill.

Lindgren, M., Bandkhold, H. (2009). Scenario planning. Communication between the future and strategy. Moscow: Olympe-business,

Mazur, I. I. (2003). Corporate management: The reference book for professionals. Moscow: The higher school.

McGoff, C. (2012). The primes: How any group can solve any problem. Hoboken, NJ: John Wiley \& Sons, Inc.

Mogutnova, N. N. (2005). Corporate culture: concept, approaches. Social researches, 4: 130-136.

Mullakhmetov, K. S., Sadriev, R. D., \& Akhmetshin, E. M. (2018). Corporate culture in management systems. European Research Studies Journal, 21(1), 519-528.

Mullakhmetov, K. S. (2018). Technological factors and management transformation in social and economic systems. European Research Studies Journal, 21(3), 230-241.

Mullins, L. J. (2003). Management and organisational behavior. New York, Minsk: New knowledge.

Neretina, E. A., \& Erastova, A. V. (2006). Management of forming and development of an organization culture (Management in social and economic systems: Studies, a benefit by general edition of the Dr. economic sciences, prof. S. D. Reznik). Penza: PGUAS. pp. $291-294$. 


\section{ENTREPRENEURSHIP AND SUSTAINABILITY ISSUES}

ISSN 2345-0282 (online) http://jssidoi.org/jesi/

2019 Volume 7 Number 2 (December)

http://doi.org/10.9770/jesi.2019.7.2(22)

Nordstrom, K. A., Ridderstrale, J. (1999). Funky Business: Talent Make Capital Dance. Falun, Sweden: BookHouse Publishing.

Panferova, N. G. (2011). A phenomenon of corporate culture in the modern world (concept and components of corporate culture). Jointstock company: questions of corporate management, 2: 45-51.

Pearce, J., \& Robinson, R. (2013). Strategic management (12th ed.). New York, St. Petersburg: Piter.

Pervakova, E. E. (2015). Development of the social and labor relations in interrelation with corporate culture of the organization in the conditions of the innovation economy (the thesis for a degree of the candidate of economic sciences). Russian Presidential Academy of National Economy and Public Administration, Moscow, Russia.

Porshnev, A. G. (2012). Management of the organization (4th ed.). Moscow: INFRA-M.

Robins, S. P., \& Coulter, M. (2004). Management (6th ed.). Moscow: Williams publishing house.

Sarkisov, S. E. (2005). Management. Dictionary reference. Moscow: Ankil.

Schein, E. H. (2004). Organizational Culture and Leadership (3rd ed.). San Francisco: Jossey Bass.

Selivanova, M. V. (2016). Development of motivation in a quality management system on the basis of improvement of corporate culture (the thesis for a degree of the candidate of economic sciences). Saint-Petersburg: Saint-Petersburg state university of economics.

Shermerorn, J., Hunt, J., \& Osborne, R. (2004). Organizational behavior (8th ed.). St. Petersburg: Piter.

Smircich, L. (1983). Concepts of culture and organizational analysis. Administrative Science Quarterly, 28(3): 339-358.

Smircich, L. (1985). Is the concept of culture a paradigm for understanding organizations and ourselves? Organizational Culture, Frost, P.I., L.F. Moore, M.R. Lousia, C.C. Lundberg and I. Martin (Eds.). SAGE Publications, Beverly Hills, pp. 55-72.

Teece, D. J., Pisano, G., \& Shuen, A. (1997). Dynamic capabilities and strategic management. Strategic Management Journal, 18(7): 509533. https://doi.org/10.1002/(SICI)1097-0266(199708)18:7<509::AID-SMJ882>3.0.CO;2-Z

Thompson, A. A. Jr., \& Strickland III, A. I. (2013). Strategic Management: Concepts and Cases (12th ed.). Moscow: Williams publishing house.

Torgunakova, E. V. (2016). Improvement of the controling mechanism corporate culture of entrepreneurial structures (the thesis for a degree of the candidate of economic sciences). Saint-Petersburg: Saint Petersburg University of Management Technologies and Economics.

Vetoshkina, T. (2009). An organization culture as the management tool personnel in the conditions of changes. Personnel officer. Personnel management, 11.

Vlasova, E. F. (2010). Corporate culture as factor of social adaptation of new workers (the thesis for a degree of the candidate of sociological sciences). Yekaterinburg: Ural State University of A.M. Gorky.

Yemelyanov, Yu., \& Khachaturian, A. (2009). Archetypes of economic and corporate culture in Russia. Problems of the theory and management practice, 12: 14-27.

Zakablutskaya, E. A. (2014). A personnel training system on the basis of corporate culture (the thesis for a degree of the candidate of sociological sciences). Moscow: Peoples' Friendship University of Russia. 


\title{
ENTREPRENEURSHIP AND SUSTAINABILITY ISSUES
}

ISSN 2345-0282 (online) http://jssidoi.org/jesi/

2019 Volume 7 Number 2 (December)

http://doi.org/10.9770/jesi.2019.7.2(22)

\begin{abstract}
Khanif Sharifzyanovich MULLAKHMETOV, PhD, Candidate of Economic Sciences, Associate Professor of the Department of Industrial Management of Naberezhnye Chelny Institute of Kazan Federal University (NChI KFU). He teaches the author's course on "Control in the management of social and economic systems" in the Master of Business Administration (MBA) program at the Graduate School of Entrepreneurship of the Kazan Federal University (Kazan). He has experience in top management of large Russian and joint companies of the engineering, construction and construction industries, in which he has been developing and implementing corporate control and internal control systems. His practical activity was evaluated by government awards and titles "Honored Economist of the Republic of Tatarstan", "Honorary Machine Builder of the Russian Federation" and others. Currently, he is a practicing independent consultant and expert on management and control problems, engaged in research of problems and prospects for adaptation and transformation of management and its basic subsystems to the conditions of the "new economy". Research interests: management, managerial control, efficiency of management and control systems.
\end{abstract}

ORCID ID: orcid.org/0000-0002-4029-2154

Ruslan Duferovich SADRIEV, PhD, Candidate of Economic Sciences, Associate Professor, Department of Industrial Management, Naberezhnye Chelny Institute of Kazan Federal University (NChI KFU). He has experience in the preparation and organization of production of large Russian engineering companies. Currently engaged in teaching special disciplines to analyze and improve the efficiency of enterprises at the economic faculty of NChI KFU and research in the field of corporate culture, the use of lean production technologies in Russian companies, improving production efficiency. Research interests: management, lean production, production efficiency.

ORCID ID: orcid.org/0000-0003-3683-9548

Elvir Munirovich AKHMETSHIN, Senior Lecturer, Department of Economics and Management, Elabuga Institute of Kazan Federal University. Currently engaged in teaching economics and management disciplines at the Faculty of Economics and Management EI KFU and research in the field of management, management control, entrepreneurship and entrepreneurship education. Research interests: management, control, internal control systems, entrepreneurship, entrepreneurship training.

ORCID ID: orcid.org/0000-0002-2576-503X

Register for an ORCID ID:

https://orcid.org/register

Copyright (C) 2019 by author(s) and VsI Entrepreneurship and Sustainability Center

This work is licensed under the Creative Commons Attribution International License (CC BY).

http://creativecommons.org/licenses/by/4.0/

C)

